\title{
USE OF POACHERS' CATCHES FOR STUDYING FISH FAUNA IN THE WATER BODIES OF THE TRANSCARPATHIAN REGION (UKRAINE)
}

\author{
Alexander DIDENKO *, Igor VELYKOPOLSKY ** and Andrey CHUKLIN *** \\ * Institute of Fisheries, Obukhivska Street 135, Kiev Ukraine, UA-03164, al_didenko@yahoo.com \\ ** Zakarpattya Fish Protection Inspection, Miru Street 53, Vynogradiv, Ukraine, UA-90300, \\ vely@meta.ua \\ *** Ukraine Fisheries Agency, Artema Street, 45-A, Kiev, Ukraine, UA-03151, chuklin@ukr.net
}

DOI: 10.1515/trser-2015-0019

KEYWORDS: Transcarpathia, Tisa River, poaching, fishing gears, catchability. ABSTRACT

We compared techniques used by poachers to capture fishes in the streams and stagnant water bodies of the Tisa River basin in Ukraine, which included: gill nets, lift nets, screen nets, electrofishing devices, spears, concussion, and beach seine. In total, 38 species were observed in poachers' catches, among which the most abundant were nase (Chondrostoma nasus), Carpathian barbel (Barbus carpathicus), chub (Squalius cephalus), crucian carp (Carassius gibelio), and minnow (Phoxinus phoxinus). The highest diversity of species was observed in gill nets (25 species in rivers and 10 in stagnant waters), lift nets (20 species in rivers and eight in stagnant waters), and electrofishing (19 species). Poachers' catches can provide information on fish species' compositions and relative abundance in montane rivers; but there are biases associated with each technique.

RÉSUMÉ: Utilisation des prises des braconniers pour l'étude de l'ichtyofaune dans les plans d'eau de la région de Zakarpattya/Transcarpatie (Ukraine).

Nous avons comparé les techniques utilisées par les braconniers pour capturer des poissons dans les cours d'eau et les plans d'eau du bassin de la rivière Tisa en Ukraine, qui comprennent les filets maillants, les filets soulevés, les filets de pêche écran, les dispositifs de pêche électrique, les harpons, la concussion et la pêche à la senne. Au total, 38 espèces ont été observées dans les prises des braconniers dont les plus abondantes ont été le nase (Chondrostoma nasus), le barbeau carpatique (Barbus carpathicus), le chevesne (Squalius cephalus), le carassin (Carassius gibelio) et le vairon (Phoxinus phoxinus). La diversité des espèces la plus élevée a été observée dans les filets maillants (25 espèces dans les rivières et 10 espèces dans les eaux d'eau stagnante), les filets soulevés (20 espèces dans les rivières et huit dans les eaux stagnantes) et la pêche électrique (19 espèces). Les captures des braconniers peuvent fournir des informations sur les compositions d'espèces de poissons et l'abondance relative des espèces dans les rivières de montagne, malgré des biais existant associés à chaque technique.

REZUMAT: Utilizarea capturilor braconierilor pentru studiul ihtiofaunei din corpurile de apă din Zakarpatia, regiunea transcarpatică (Ucraina).

Am comparat tehnici folosite de braconieri pentru a prinde pești atât în ecosisteme lotice, cât și lentice din bazinul Tisei, în Ucraina. Se utilizează setci, plase acționate prin ridicare, plase sită, aparate pentru electrofishing, sulițe, explozibil și năvodul utilizat de pe maluri. În total, au fost observate 38 specii, capturate de braconieri, printre care cele mai abundente au fost: scobarul (Chondrostoma nasus), mreana (Barbus carpathicus), cleanul (Squalius cephalus), carasul (Carassius gibelio) și boișteanul (Phoxinus phoxinus). Cea mai mare diversitate a speciilor a fost observată în setci ( 25 specii în râuri și 10 în apele stătătoare), plase acționate prin ridicare (20 specii în râuri și opt în apele stătătoare) și electrofishing (19 specii). Capturile braconierilor pot furniza informații cu privire la compoziția specifică a ihtiofaunei și abundența relativă a speciilor din râurile montane, dar fiecare tehnică are limite asociate. 


\section{INTRODUCTION}

Watercourses of the Tisa River basin (Danube River system) flow from the western slopes of the Carpathian Mountains and within Ukraine, they include about 9,500 rivers and streams for a total length of more than $19,000 \mathrm{~km}$ (Shmidt, 1978). These lotic systems are rather unique ecosystems, including the highest diversity of fish species in Ukraine, many being endemic. According to different authors (Movchan, 2000), from 49 to 61 taxa of species and sub-species rank and inhabit water bodies of the Tisa River basin within Ukraine. Stocks of some fish species were commercially exploited as recently as the first half of the 20th century (Protasov, 1948), but most of them have significantly declined due to various factors; the majority of which are due to human impact in the area (Movchan, 2000). Little information is available on the current state of local fish communities because no complex scientific surveys have been conducted in these rivers. In Ukraine, much more attention is given to fishes of large water bodies, and stocks of which are exploited commercially.

Fish sampling provides necessary information for fisheries, scientists and managers on fish abundance, species' composition, stock state, and other factors. However, collecting data in the field can be expensive, time consuming and is often limited to few water bodies or sampling sites. Therefore, in addition to fish surveys research, samples of recreational or commercial creels are often used to collect information about fisheries (Malvestuto, 1996; Fabrizio and Richards, 1996).

Recreational fishing in rivers of the Ukrainian Carpathians is very popular among local people and tourists. According to Ukrainian Recreational Fishing Regulations, only angling gears are allowed for fish capture in these rivers. However, due to the lack of control and the remoteness of many mountain rivers, illegal fishing is a widespread activity in this region. The most common poachers' gears used include various nets (gill nets, drift nets, lift nets, etc.) and electrofishing devices. Less common fishing methods include using spears and concussion (Didenko et al., 2011). If illegal fishing gears (gill nets) are found by local fish protection inspectors, or if poachers are caught on the fishing site with their gears and catch, a protocol of offence is filed; it includes information such as the number of fishes caught, a description of the fishing gear used, and occasionally the length and weight of the fish species caught. The data can provide additional information for fisheries and biologists, especially when they are unable to sample fish over the entire region.

Thus, the aim of this study was to investigate the possibility of using poachers' catches for studying fish fauna in the Ukrainean Carpathian Rivers and to compare the efficiency of different illegal fishing gears.

\section{MATERIALS AND METHODS}

Different types of data were collected during 2008-2011 in the Transcarpathian (Zakarpattya) region of Ukraine.

We analyzed poachers' catches and fishing gears (if possible) confiscated by Regional Fish Protection Inspectorate in different areas of the Transcarpathian region, as well as protocols of offence registered for each poaching event (Figs. 1 and 2).

Catches from rivers and stagnant water bodies (lakes, ponds, canals) were treated separately. 
Catches of the following illegal fishing gears and techniques were analyzed (see also Didenko and Velykopolsky, 2011):

- gill nets, which ranged in dimensions of 20-100 m in length, 1.0-2.0 m in depth, a bar mesh size of 10 to $40 \mathrm{~mm}$ (54 protocols at 31 sites in eight rivers; 21 protocols at 19 sites in 17 stagnant water bodies);

- lift nets, which were constructed of a $1.0 \times 1.0$ to $4.0 \times 4.0 \mathrm{~m}, 10-30 \mathrm{~mm}$ bar mesh on a horizontally oriented rectangular sheet of netting, mounted on two crossed metal or plastic arcs attached to a handle. Fish were caught by abruptly lifting the net out of the water after they were concentrated over the net at intervals of one to 30 minutes (27 protocols at 18 sites in 10 rivers; 11 protocols at nine sites in nine stagnant water bodies);

- screen nets, which consisted of a vertically oriented sheet of netting attached to a metallic bottom line and top line attached with ropes to a handle. Dimensions of screen nets ranged from lengths of 0.7-1.5 m, depths of 0.7-1.5 m, and bar mesh sizes of 10 to $30 \mathrm{~mm}$. Fish were captured by holding the net under the water above the bottom or in the water column in current for periods of five to 30 minutes. Fish in screen nets were caught by gilling or wedging (36 protocols at 16 sites in four rivers);

- electrofishing devices, which were usually home-made and portable apparatuses with various constructions and power characteristics (16 protocols of offence at 15 sites in seven rivers);

- spears, which were usually constructed of a rake or table fork attached to an elongated handle (12 protocols of offence at seven sites in seven rivers);

- concussion consisted of striking large stones protruding from the water with a sledge hammer as strongly as possible. Concussed fish were then collected by dip nets and by hand (11 protocols of offence at nine sites in four rivers);

- beach seines (length three to $20 \mathrm{~m}$, height $0.5-2.0 \mathrm{~m}$, mesh size from $10 \times 10$ to $30 \times 30$ $\mathrm{mm}$ ), which were used mainly in stagnant water bodies (nine protocols at seven sites in five stagnant water bodies).

The seized fish were identified and counted. Due to the fact that different fishing gears of the same type were not standardized (e.g. nets had different mesh sizes and dimensions) and fishing efforts were not known, catches were pooled by numbers of species caught in each gear type (all rivers together). Then we calculated the composition percentage of species captured using each fishing gear type.

Next, poachers' gears was compared by species captured and by rivers, to see if there were differences among methods in its ability to catch different species and if there were differences among rivers. While comparing different gears, we used the number of species caught per gear, per fishing site, and per day/night as a unit of catchability. For the comparison of rivers, we excluded those for which only one site was fished.

A one-way analysis of variance (ANOVA) was performed to test the differences among fishing gear and among rivers. A multiple comparisons procedure (Tukey-Kramer, $\alpha=$ 0.05) was used to compare all possible pairs of means of fish caught by each method and separately in each river. Data (number of fish caught) were log transformed to satisfy the assumptions of normality of ANOVA. All statistical calculations were performed with JMP IN 5.0 software. 


\section{RESULTS AND DISCUSSION}

In total, 38 species belonging to 10 families (Thymallidae, Salmonidae, Cyprinidae, Nemacheilidae, Ictaluridae, Esocidae, Lotidae, Percidae, Cottidae and Centrarchidae) were observed in poachers' catches (Figs. 1 and 2; Tabs. 1 and 2). Of them, 34 species were recorded for rivers and 13 species for stagnant waters. The most abundant were cyprinids, which were represented by 23 species (60.5\%). Percids were represented by five species (13.2\%), salmonids by three species (7.9\%), and the others by one species (2.6\% each). Among the fish caught in poachers' fishing gears, 10 species are listed as endangered in the current edition of the Red Book of Ukraine (Thymallus thymallus, Hucho hucho, Telestes souffia, Barbus barbus, Barbus carpathicus, Romanogobio uranoscopus, Lota lota, Gymnocephalus schraetser, Zingel zingel, and Zingel streber).

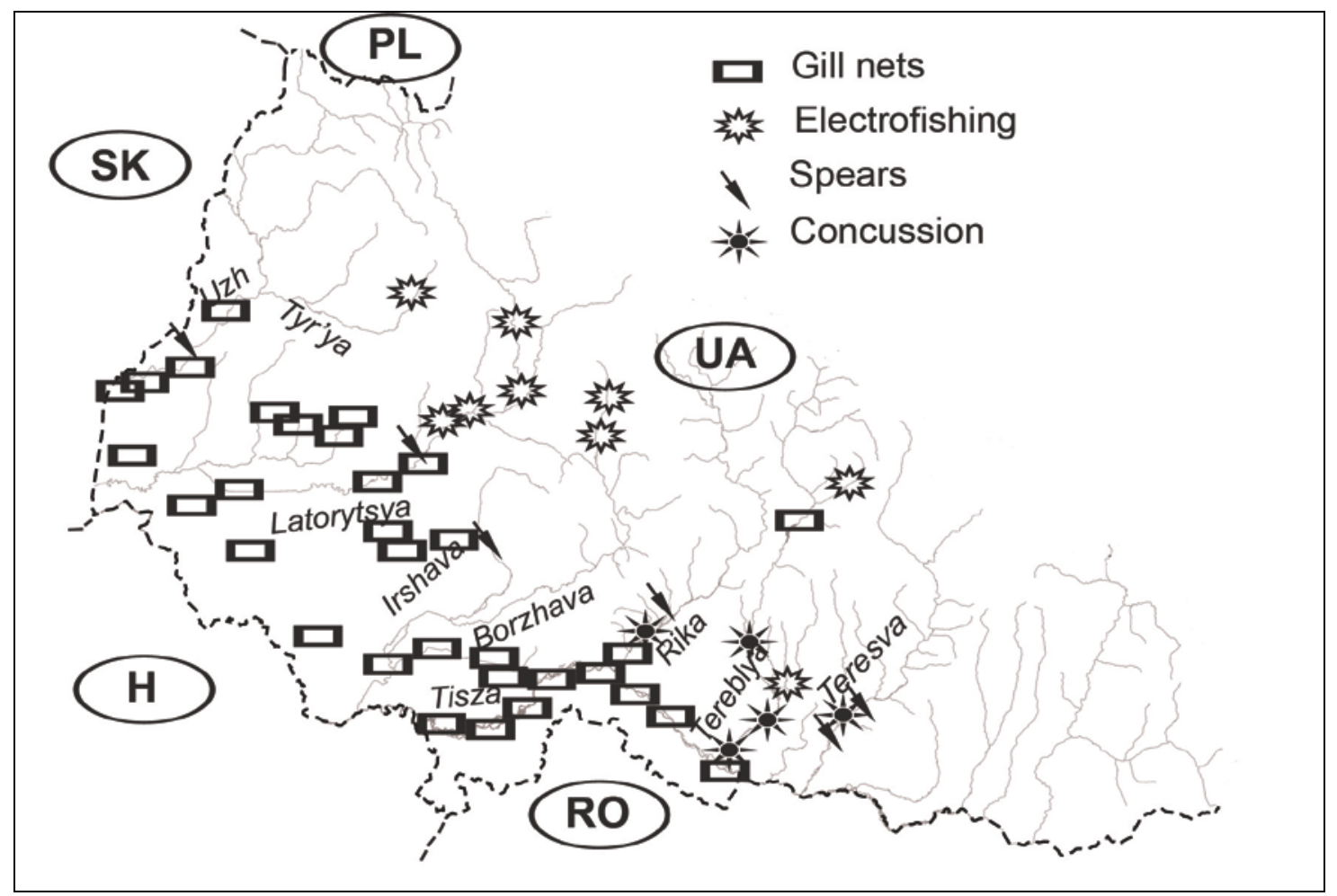

Figure 1: Sites locations of poaching events with gill nets, electrofishing, spears and concussion in the Zakarpattya region of Ukraine.

Four species (Cyprinus carpio, Hypophthalmichthys sp., Ctenopharyngodon idella, and Lepomis gibbosus) were caught only in stagnant waters. Nine species (Squalius cephalus, Rutilus rutilus, Scardinius erythrophthalmus, Abramis brama, Carassius gibelio, Ameiurus nebulosus, Esox lucius, Lota lota and Perca fluviatilis) were observed in catches from both rivers and stagnant water bodies. The remaining 23 species were recorded only for rivers.

The highest diversity of species was observed in gill net catches, 25 species in rivers and 10 in stagnant waters (Tabs. 1 and 2). The most abundant were Chondrostoma nasus, Squalius cephalus, Barbus carpathicus, and Carassius gibelio each of which composed more than $8 \%$ of the catch by numbers. In stagnant waters the most abundant were Carassius gibelio and Cyprinus carpio, which are typical pond fishes. 


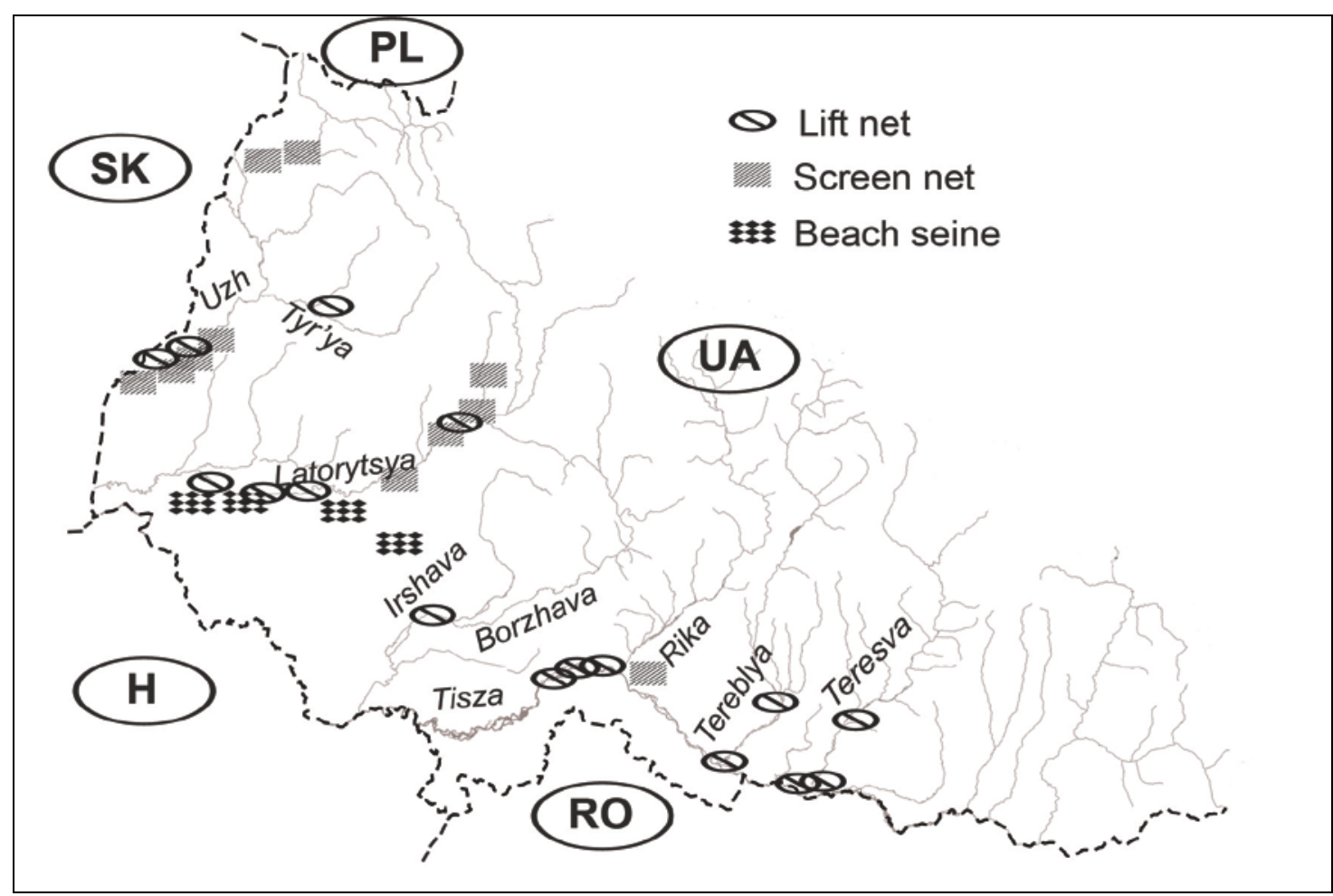

Figure 2: Site locations of poaching events with lift net, screen net and beach seine in the Zakarpattya region of Ukraine.

Table 1: Species' compositions (\%) of poachers' fishing gears in rivers and streams of the Tisa River basin in the Zakarpattya region of Ukraine; the average for 2008-2011.

\begin{tabular}{|l|c|c|c|c|c|c|}
\hline \multirow{2}{*}{ Species } & \multicolumn{7}{|c|}{ Fishing gears/techniques } \\
\cline { 2 - 7 } & $\begin{array}{c}\text { Gill } \\
\text { nets }\end{array}$ & $\begin{array}{c}\text { Lift } \\
\text { net }\end{array}$ & $\begin{array}{c}\text { Screen } \\
\text { net }\end{array}$ & $\begin{array}{c}\text { Concu- } \\
\text { sion }\end{array}$ & Spearing & $\begin{array}{c}\text { Electro- } \\
\text { fishing }\end{array}$ \\
\hline $\begin{array}{l}\text { Hucho } \\
\text { hucho }\end{array}$ & 0.28 & 0.31 & - & - & 1.52 & - \\
\hline $\begin{array}{l}\text { Oncorhynchus } \\
\text { mykiss }\end{array}$ & - & - & - & - & - & 0.91 \\
\hline $\begin{array}{l}\text { Salmo trutta m. } \\
\text { fario }\end{array}$ & - & - & - & - & - & 1.37 \\
\hline $\begin{array}{l}\text { Thymallus } \\
\text { thymallus }\end{array}$ & - & 0.61 & 0.45 & 0.65 & - & 1.82 \\
\hline $\begin{array}{l}\text { Chondrostoma } \\
\text { nasus }\end{array}$ & 37.01 & 18.38 & 48.21 & 0.65 & 20.45 & 46.58 \\
\hline $\begin{array}{l}\text { Squalius } \\
\text { cephalus }\end{array}$ & 11.30 & 3.37 & 8.48 & 3.68 & 14.39 & 8.36 \\
\hline $\begin{array}{l}\text { Leuciscus } \\
\text { leuciscus }\end{array}$ & - & - & - & - & - & 3.12 \\
\hline $\begin{array}{l}\text { Leuciscus } \\
\text { idus }\end{array}$ & 0.28 & - & - & - & - & - \\
\hline
\end{tabular}


Table 1 (continuing): Species' compositions (\%) of different poachers' fishing gears in rivers and streams in Tisa Basin in the Zakarpattya area of Ukraine; an average for 2008-2011.

\begin{tabular}{|c|c|c|c|c|c|c|}
\hline \multirow[b]{2}{*}{ Species } & \multicolumn{6}{|c|}{ Fishing gears/techniques } \\
\hline & $\begin{array}{l}\text { Gill } \\
\text { nets }\end{array}$ & $\begin{array}{l}\text { Lift } \\
\text { net }\end{array}$ & $\begin{array}{c}\text { Screen } \\
\text { net }\end{array}$ & $\begin{array}{l}\text { Concu- } \\
\text { sion }\end{array}$ & Spearing & $\begin{array}{l}\text { Electro- } \\
\text { fishing }\end{array}$ \\
\hline $\begin{array}{l}\text { Telestes } \\
\text { souffia }\end{array}$ & 1.13 & 0.77 & - & 4.98 & 0.76 & 3.27 \\
\hline $\begin{array}{l}\text { Vimba } \\
\text { vimba }\end{array}$ & 1.84 & 1.07 & - & - & - & 0.15 \\
\hline $\begin{array}{l}\text { Barbus } \\
\text { barbus }\end{array}$ & 4.66 & 0.61 & 6.70 & 1.95 & 5.30 & 1.44 \\
\hline $\begin{array}{l}\text { Barbus } \\
\text { carpathicus }\end{array}$ & 9.04 & 8.12 & 26.34 & 29.00 & 55.30 & 12.39 \\
\hline $\begin{array}{l}\text { Romanogobio } \\
\text { uranoscopus }\end{array}$ & 0.14 & 0.31 & 0.45 & 1.30 & 0.76 & - \\
\hline $\begin{array}{l}\text { Gobio } \\
\text { carpathicus }\end{array}$ & 0.56 & 0.61 & - & 0.22 & - & 0.76 \\
\hline $\begin{array}{l}\text { Rutilus } \\
\text { rutilus }\end{array}$ & 0.28 & 1.07 & 0.45 & - & - & 2.36 \\
\hline $\begin{array}{l}\text { Scardinius } \\
\text { erythrophthalmus }\end{array}$ & 0.28 & - & 5.80 & - & - & - \\
\hline $\begin{array}{l}\text { Blicca } \\
\text { bjoerkna }\end{array}$ & 4.24 & 0.61 & - & - & - & - \\
\hline $\begin{array}{l}\text { Abramis } \\
\text { brama }\end{array}$ & 4.52 & 0.31 & - & - & - & - \\
\hline $\begin{array}{l}\text { Alburnus } \\
\text { alburnus }\end{array}$ & 3.11 & 48.09 & 2.23 & 1.73 & 0.76 & 3.34 \\
\hline $\begin{array}{l}\text { Alburnoides } \\
\text { bipunctatus }\end{array}$ & - & 6.43 & - & 2.16 & 0.76 & 4.18 \\
\hline $\begin{array}{l}\text { Phoxinus } \\
\text { phoxinus }\end{array}$ & - & 3.52 & - & 47.19 & - & 6.61 \\
\hline $\begin{array}{l}\text { Aspius } \\
\text { aspius }\end{array}$ & 0.56 & - & - & - & - & - \\
\hline $\begin{array}{l}\text { Tinca } \\
\text { tinca }\end{array}$ & - & 0.15 & - & - & - & - \\
\hline $\begin{array}{l}\text { Carassius } \\
\text { gibelio }\end{array}$ & 8.33 & 4.90 & - & 0.87 & - & 0.08 \\
\hline $\begin{array}{l}\text { Barbatula } \\
\text { barbatula }\end{array}$ & - & - & - & 5.41 & - & - \\
\hline $\begin{array}{l}\text { Ameiurus } \\
\text { nebulosus }\end{array}$ & 0.71 & - & - & - & - & - \\
\hline $\begin{array}{l}\text { Esox } \\
\text { lucius } \\
\end{array}$ & 3.39 & 0.15 & - & - & - & - \\
\hline $\begin{array}{l}\text { Lota } \\
\text { lota }\end{array}$ & 1.27 & - & - & - & - & 0.15 \\
\hline $\begin{array}{l}\text { Cottus } \\
\text { poecilopus }\end{array}$ & - & - & - & - & - & 3.04 \\
\hline
\end{tabular}


Table 1 (continuing): Species' compositions (\%) of different poachers' fishing gears in rivers and streams in Tisa Basin in the Zakarpattya area of Ukraine; the average for 2008-2011.

\begin{tabular}{|l|c|c|c|c|c|c|}
\hline \multirow{2}{*}{ Species } & \multicolumn{7}{|c|}{ Fishing gears/techniques } \\
\cline { 2 - 7 } & Gill & $\begin{array}{c}\text { Lift } \\
\text { nets }\end{array}$ & $\begin{array}{c}\text { Screen } \\
\text { net }\end{array}$ & $\begin{array}{c}\text { Concu- } \\
\text { sion }\end{array}$ & Spearing & $\begin{array}{c}\text { Electro- } \\
\text { fishing }\end{array}$ \\
\hline $\begin{array}{l}\text { Perca } \\
\text { fluviatilis }\end{array}$ & 3.81 & $\mathbf{0 . 6 1}$ & $\mathbf{0 . 8 9}$ & $\mathbf{0 . 2 2}$ & - & - \\
\hline $\begin{array}{l}\text { Gymnocephalus } \\
\text { cernua }\end{array}$ & 0.14 & - & - & - & - & - \\
\hline $\begin{array}{l}\text { Gymnocephalus } \\
\text { schraetser }\end{array}$ & 1.69 & - & - & - & - & - \\
\hline $\begin{array}{l}\text { Zingel } \\
\text { zingel }\end{array}$ & 1.27 & - & - & - & - & - \\
\hline $\begin{array}{l}\text { Zingel } \\
\text { streber }\end{array}$ & 0.14 & - & - & - & - & 0.08 \\
\hline
\end{tabular}

Table 2: Species' percent compositions (\%) of different poachers' fishing gears in stagnant water bodies in the Zakarpattya region of Ukraine; an average for 2008-2011. ** Includes Hypophthalmichthys molitrix and Hypophthalmichthys nobilis and their hybrids.

\begin{tabular}{|l|c|c|c|}
\hline \multirow{2}{*}{ Species } & \multicolumn{3}{|c|}{ Fishing gear/techniques } \\
\cline { 2 - 4 } $\begin{array}{l}\text { Squalius } \\
\text { cephalus }\end{array}$ & Gill nets & Lift net & Beach seine \\
\hline $\begin{array}{l}\text { Rutilus } \\
\text { rutilus }\end{array}$ & - & 0.48 & - \\
\hline $\begin{array}{l}\text { Scardinius } \\
\text { erythrophthalmus }\end{array}$ & -46 & 0.48 & 42.77 \\
\hline $\begin{array}{l}\text { Abramis } \\
\text { brama }\end{array}$ & 4.07 & 0.48 & - \\
\hline $\begin{array}{l}\text { Cyprinus } \\
\text { carpio }\end{array}$ & 16.54 & 0.96 & - \\
\hline $\begin{array}{l}\text { Carassius } \\
\text { gibelio }\end{array}$ & 71.60 & 0.48 & - \\
\hline $\begin{array}{l}\text { Ctenopharyngodon } \\
\text { idella } * *\end{array}$ & 0.12 & - & 33.96 \\
\hline $\begin{array}{l}\text { Hypophthalmichthys } \\
\text { ssp. } * *\end{array}$ & 0.49 & - & - \\
\hline $\begin{array}{l}\text { Ameiurus } \\
\text { nebulosus }\end{array}$ & 2.72 & 5.26 & 10.06 \\
\hline $\begin{array}{l}\text { Esox } \\
\text { lucius }\end{array}$ & 0.62 & - & 12.58 \\
\hline $\begin{array}{l}\text { Lota } \\
\text { lota }\end{array}$ & 0.25 & 0.48 & - \\
\hline $\begin{array}{l}\text { Lepomis } \\
\text { gibbosus }\end{array}$ & 0.12 & - & - \\
\hline Perca fluviatilis & - & - & - \\
\hline
\end{tabular}


These data are consistent with the data obtained during a fish research survey conducted on Teresva and Irshava Carpathian rivers, with the use of gill nets of 21-40 mm mesh sizes (Didenko et al., 2010). In both studies, the most abundant species were Chondrostoma nasus (36.2\% in the research survey - average for two studied rivers, and 37.0\% in poachers' gear), Squalius cephalus (9.0\% in the research survey and $11.3 \%$ in poachers' gears) and Barbus carpathicus (13.7\% in the research survey and $9.0 \%$ in poachers' gear). However, 37 species in total were caught by research gill nets and 29 were observed in poachers' gill nets. In the research catches, the species that ranked the 4th and 5th in the abundance list were Alburnoides bipunctatus (6.9\%) and Alburnus alburnus (6.0\%), while only Alburnus alburnus was observed in poachers' gear (3.1\%, ranked the 10th). Carassius gibelio was much more abundant in poachers' gill nets (8.3\%, ranked the 4th), than in research ones $(2.0 \%$, ranked the 13th). Poachers select more valuable and larger fish and therefore often set their nets in sheltered sites and among aquatic vegetation hidden from direct sight where crucian carp is more common; while such rheophil species as Alburnus alburnus and Alburnoides bipunctatus prefer open waters and are furthermore often discarded.

Twenty species were caught via the lift net in rivers, among which the most abundant were Alburnus alburnus, Chondrostoma nasus and Barbus carpathicus (Tab. 1). Eight species were observed in lift net catches in stagnant waters, among which the most abundant was Carassius gibelio (Tab. 2).

Lift net catches significantly differed from gill net catches. The lift nets were found to be effective for catching small schooling species such as Alburnus alburnus, which inhabit the water column; as well as juveniles of larger species such as: Chondrostoma nasus, Barbus carpathicus and Carassius gibelio. These gears can be used in a wider range of habitats, from lentic environments to shallow montane streams. However, large and fast fishes usually escape from these nets.

Various types of lift nets are successfully used for sampling fish larvae (Mehner et al., 1996; Rooker et al., 1996), and adults (Pot, 1984; Pyka, 1999), especially in tropical water bodies (Whitfield, 1993; Mtsambiwa, 1996; Ahmed and Hambrey, 2005), where they are often used as traditional fishing gears by local people. This active fishing gear can be useful for collecting information on species' composition and collecting fish for additional purposes when no data on their abundance is necessary such as study of fish diets and diseases.

Ten species were caught by the screen nets (Tab. 1). Screen nets were found to be the least effective as they caught the lowest amount of fishes among the analyzed fishing gears. Similar to gill nets, the most frequently captured fishes were Chondrostoma nasus, Barbus carpathicus and Squalius cephalus, which is probably because both types of gears are vertically oriented nets and have similar biases related to fish selection.

Fourteen species were caught by concussion with the aid of sledge hammers and the dominant species among them were Phoxinus phoxinus and Barbus carpathicus (Tab. 1). Concussion of fish with the aid of sledge hummers seems to be less selective than spearing. This method can be used in similar biotopes as spears, but it requires large stones to serve as resonators, which transform the energy of the hit into shock waves that travel through the water. Concussion is more suitable for very shallow mountain streams, which are rich in such stones. As it can be seen from the species' composition observed in catches obtained by this technique, it seems that some fishes are more vulnerable to concussion than others. The most sensitive seems to be minnow and Carpathian barbel, which significantly exceeded all other species in catches using this method. However, it may also be due to the fact that concussion was used in streams where these species dominated. 
Nine species were caught using spears, among which the Barbus carpathicus predominated significantly, while other abundant species included Chondrostoma nasus and Squalius cephalus. Hand spears are rarely used as gear for fish sampling and only for studies when no data on fish abundance is necessary (Webb and Kingsford, 1992). Poachers use them in very shallow streams with transparent water that allows direct observation of the target fish. Usually these habitats are located in mountain and sub-mountain regions of the Carpathians. During the fishing process, the poacher stays on the river bank, on large stones or wades cautiously in the water looking for fish. The spear is a highly selective gear because the person usually selects the largest individuals if several fish are in the field of view. Additionally, this fishing method is species-selective (only nine species caught) and is directed mainly towards the bottom dwelling and relatively large fish such Chondrostoma nasus and Squalius cephalus, which are easier to hit by spear. However, small bottom dwelling species such as Cottus poecilopus and Cottus gobio may remain inaccessible for this gear because they usually hide under stones or snags and are not seen from the waters' surface. It seems that fast swimming species inhabiting the water column such as salmonids, Alburnus alburnus and Alburnoides bipunctatus are difficult to capture with spears. The exception is Hucho hucho, large individuals of which capture is possible with the aid of spearing on their spawning grounds when this fish becomes less alert.

In electrofishing catches, 19 species were observed, among which Chondrostoma nasus and Barbus carpathicus (Tab. 1) dominated. Electrofishing devices were found to be the least selective gear and the only one that captured Thymallus thymallus, Salmo trutta m. fario and Oncorhynchus mykiss. They are widely used worldwide and are the most effective gears for fish sampling in mountain rivers (Reynolds, 1996; Dunham et al., 2009), but are legally prohibited in Ukraine, including their use for scientific purposes. Electrofishing was found to be the most effective technique for fishing as it caught the highest number of fish (all species combined) per poacher per fishing trip. Lower numbers of species caught by this method in comparison with gill nets can be explained by the fact that poachers most often use portable electrofishing devices, which can be applied in a limited number of biotopes such as very shallow mountain and sub-mountain streams (usually $<50 \mathrm{~cm}$ depth) characterized by lower biodiversity than lower sections of rivers where gill net are commonly used. Poachers also tend to use these gears in more remote areas because more severe penalties are imposed for fishing with them.

In beach seine catches, methods used mainly on shallows of stagnant water bodies with relatively flat bottoms, five species were observed, among which the most abundant were Rutilus rutilus and Carassius gibelio. Beach seines are widely used throughout the world for commercial fishery and research fish sampling both in rivers and stagnant waters with various goals including studies of fish abundance and species composition (Hayes et. al., 1996; Port et al., 2006; Horváth et al., 2012). They can very easily be made and deployed by illegal fishermen.

Such species as Leuciscus idus, Aspius aspius, Ctenopharyngodon idella, Hypophthalmichthys spp., Ameiurus nebulosus, Lepomis gibbosus, Gymnocephalus cernua, Gymnocephalus schraetser and Zingel zingel were caught only in gill nets. A single occurrence of Tinca tinca was observed in the lift net only. Salmo trutta, Oncorhynchus mykiss, Leuciscus leuciscus and Cottus poecilopus were observed only in electrofishing catches, while Barbatula barbatula was caught only by concussion. 
Fishing methods differed in the number of fishes captured $(P<0.001)$. The difference of electrofishing catchability from other gears was significant (except concussion), while screen netting differed significantly only from electrofishing and concussion, but the difference between various netting gears and spearing was insignificant $(P>0.05)$. Netting techniques and spearing captured relatively equal numbers of fish, all species combined. Electrofishing captured the highest number of fishes while screen net captured the lowest.

The number of fishes caught differed statistically significantly by rivers, but remained moderate $(P=0.024)$. A significant difference was observed only between Tereblya River, where the largest number of fish were caught, and Borzhava River, where the lowest number of fish were caught $(P>0.05)$.

As for differences between different rivers, they can be attributed to fishing gears and techniques used as well as different species' compositions and fish densities. The highest amount of fish caught in Tereblya River is due to the fact that mostly lift nets and concussions were deployed here, which captured large quantities of small juvenile fish. In Borzhava River, with the lowest amount of fish catches, the catches were obtained using gill nets and lift nets.

\section{CONCLUSIONS}

An analysis of catches from illegal fishing gears can provide information on fish species' composition and relative abundances of species in mountain rivers when such fishing activity occurs in the water body of interest and where research fish surveys cannot be conducted. This information is relatively easy to obtain and is of low cost for fisheries' scientists. However, there are biases associated with the analyzed fishing gears because poachers typically select the most valuable and large fishes, while small and coarse species can be underrepresented in their catches. Therefore, only general inferences can be made from such data.

According to our results, 38 species were caught by illegal fishing gears in rivers and stagnant waters of the Tisa basin within Ukraine and the most abundant were Chondrostoma nasus, Barbus carpathicus, Squalius cephalus, Carassius gibelio and Phoxinus phoxinus (depending on habitat). As no research fish surveys were conducted in these rivers with the use of non-selective gears such as electrofishing, it was not possible to compare these results with scientific data. 


\section{ACKNOWLEDGEMENTS}

The authors would like to thank inspectors of the Zakarpattya Fish Protection Inspection for assisting in data collection. 


\section{REFERENCES}

1. Ahmed K. K. U. and Hambrey J. B., 2005 - Studies on the fish catch efficiency of different types of fishing gear in Kaptai Reservoir, Bangladesh, Lakes and Reservoirs: Research and Management, 10, 221-234.

2. Didenko A. V. and Velykopolsky I. I., 2011 - Illegal fishing in the Tisza River drainage within Ukraine: a threat for local fish stocks? Archives of Polish Fisheries, 19, 249-257.

3. Didenko A. V., Velykopolskyi I. I. and Ustych V. I., 2010 - Efektyvnist vykorystania de-jakykh znariad lovu dlia provedenia ichtiologicznoji zjomky v riczkakh Zakarpatia, Rybogospodars'ka Nauka Ukrainy, 12, 40-46. (in Ukrainean)

4 Dunham J. B., Rosenberger A. E., Thurow R. F., Dolloff C. A. and Howell P. J., 2009 Coldwater fish in wadable streams, in Bonar S. A., Hubert W. A. and Willis D. W. (eds), Standard methods for sampling North American freshwater fishes, American Fisheries Society, Bethesda, Maryland, 119-138.

5. Fabrizio M. C. and Richards R. A., 1996 - Commercial fisheries surveys, in Murphy B. R. and Willis D. W. (eds), Fisheries techniques, 2nd ed., American Fisheries Society, Bethesda, Maryland, 625-650.

6. Hayes D. B., Ferreri C. P. and Taylor W. W., 1996 - Active fish capture methods, in Murphy B. R. and Willis D. W. (eds), Fisheries techniques, 2nd ed., American Fisheries Society, Bethesda, Maryland, 193-220.

7. Horváth J., Pekárik L., Hajdú J. and Tomeček J., 2012 - Fish diversity of the lowland stretches of Morava and Váh rivers (Danube drainage, Slovakia), Pisces Hungarici, 6, 95-100.

8. Malvestuto S. P., 1996 - Sampling the recreational creel, in Murphy B. R. and Willis D. W. (eds), Fisheries techniques, 2nd edition American Fisheries Society, Bethesda, Maryland, 591624.

9. Mehner T., Schultz H., Bauer D., Herbst R., Voigt H. and Benndorf J., 1996 - Intraguild predation and cannibalism in age-0 perch (Perca fluviatilis) and age-0 zander (Stizostedion lucioperca): Interactions with zooplankton succession, prey fish availability and temperature, Annales Zoologici Fennici, 33, 353-361.

10. Movchan Y. V., 2000 - Sovremiennyi vidovoi sostav kruglorotykh i ryb basseyna rieki Tisy v predelakh Ukrainy (Current species composition of cyclostomes and fishes of the Tisa River basin within Ukraine), Voprosy Ikhtiologii, 40, 121-123. (in Russian)

11. Mtsambiwa M. Z., 1996 - Evaluation of lift-net selectivity in the freshwater sardine Limnothrissa miodon fishery on Lake Kariba, Zimbabwe, Fisheries Research, 26, 373-379.

12. Port C. B., Coker G. A., Ming D. L. and Randall R. G., 2006 - A review of fish sampling methods commonly used in Canadian freshwater habitats, Canadian Technical Report of Fisheries and Aquatic Sciences, 2604, 51.

13. Pot W., Noakes D. L. G., Ferguson M. M. and Coker G., 1984 - Quantitative sampling of fishes in a simple system: failure of conventional methods, Hydrobiologia, 114, 249-254.

14. Protasov A. A., 1948 - Sostojanie zapasov ruczjevoi i raduzhnoi foreli v rekakh Zakarpatskoi Oblasti, Otcjot Nauchno-Issledovatelskogo Instituta ryborazvedenia, 1946, Lvov, 77. (in Russian)

15. Pyka J., 1999 - Daily foraging cycle and daily food ration of roach Rutilus rutilus (L.) in Bachotek lake (Brodnickie lakeland) in spring, Archives of Polish Fisheries, 7, 353-358.

16. Reynolds J. B., 1996 - Electrofishing, in Murphy B. R. and Willis D. W. (eds), Fisheries techniques, 2nd ed. American Fisheries Society, Bethesda, Maryland, 221-253.

17. Rooker J. R., Dennis J. D. and Goulet D., 1996 - Sampling larval fishes with a nightlight lift-net in tropical inshore waters, Fisheries Research, 26, 21-15.

18. Shmidt T. S. (ed.), 1978 - Resursy poverkhnostnykh vod Ukrainy, 6, 1, Gidrometeoizdat, Leningrad, 490. (in Russian)

19. Webb R. O. and Kingsford M. J., 1992 - Protogynous hermaphroditism in the half-banded sea perch, Hypoplectrodes maccullochi (Serranidae), Journal of Fish Biology, 40, 951-961.

20. Whitfield A. K., 1993 - Fish biomass estimates from the littoral zone of an estuarine coastal lake. Estuaries, 16, 280-289. 